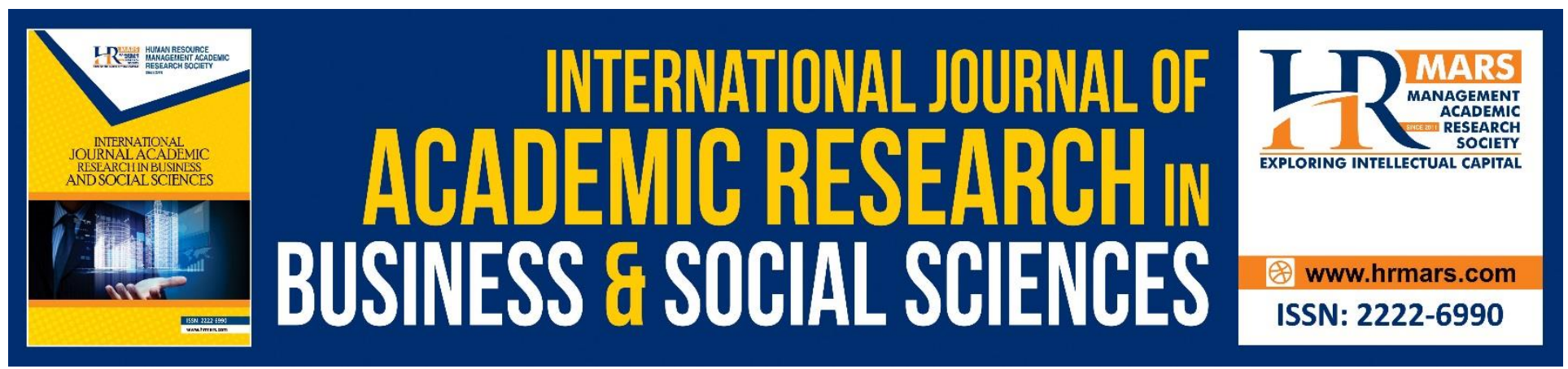

\title{
Bank Loan or Financing for Weddings Ceremonies: Causes and Reasons
}

Fatimah-Salwa Abd. Hadi, Mohd Yahya Mohd Hussin, Fidlizan Muhammad, Azila Abdul Razak, Nurhanie Mahjom

To Link this Article: http://dx.doi.org/10.6007/IJARBSS/v9-i1/5895

DOI: $10.6007 /$ IJARBSS/v9-i1/5895

Received: 29 Nov 2018, Revised: 11 Dec 2019, Accepted: 04 Jan 2019

Published Online: 27 Jan 2019

In-Text Citation: (Hadi, Hussin, Muhammad, Razak, \& Mahjom, 2019)

To Cite this Article: Hadi, F.-S. A., Hussin, M. Y. M., Muhammad, F., Razak, A. A., \& Mahjom, N. (2019). Bank Loan or Financing for Weddings Ceremonies: Causes and Reasons. International Journal of Academic Research Business and Social Sciences, 9(1), 1409-1417.

Copyright: (C) 2019 The Author(s)

Published by Human Resource Management Academic Research Society (www.hrmars.com)

This article is published under the Creative Commons Attribution (CC BY 4.0) license. Anyone may reproduce, distribute, translate and create derivative works of this article (for both commercial and non-commercial purposes), subject to full attribution to the original publication and authors. The full terms of this license may be seen

at: http://creativecommons.org/licences/by/4.0/legalcode

Vol. 9, No. 1, 2019, Pg. 1409 - 1417

http://hrmars.com/index.php/pages/detail/IJARBSS

JOURNAL HOMEPAGE

Full Terms \& Conditions of access and use can be found at http://hrmars.com/index.php/pages/detail/publication-ethics 


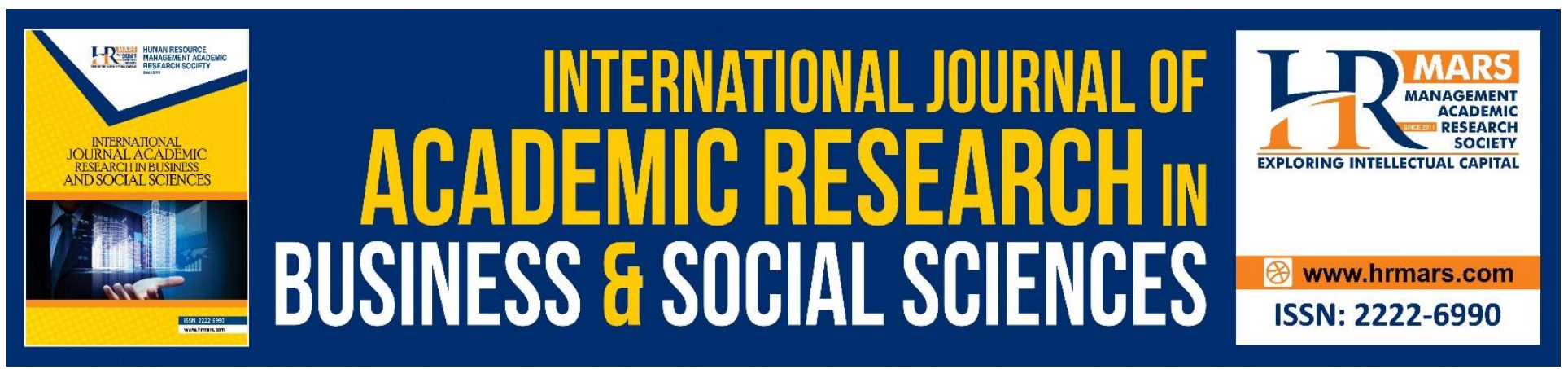

\title{
Bank Loan or Financing for Weddings Ceremonies: Causes and Reasons
}

\author{
Fatimah-Salwa Abd. Hadi, Mohd Yahya Mohd Hussin, Fidlizan \\ Muhammad, Azila Abdul Razak, Nurhanie Mahjom \\ Faculty of Management and Economic, Universiti Pendidikan Sultan Idris, Tanjung Malim, Perak, \\ Malaysia. \\ Email: fatimahsalwa@fpe.upsi.edu.my
}

\begin{abstract}
Today's wedding expenses kept increasing and have created difficulties for many parties especially the couple who wants to get married. As an alternative, most couple have obtained loans or financing from banks. There are many studies debating the issue and conclude that this situation has not only resulted in the high rate of indebtedness of the young generation, but also has led to divorces. Therefore, the objective of this study is to identify the main reason as to why bridal couple get loans or financing from the bank, the amount of financing taken, the repayment period and the types of banks offering loans or financing. The questionnaire was used as a research instrument to obtain the required information. A total of 204 respondents were selected through a snow ball sampling technique. The findings of descriptive analysis showed that the main reason couple get a loan or bank funding was because they have no money at all to perform a wedding ceremony. In addition, the repayment periods for the majority of respondents were also longer than 5 years. With that, the study suggested that the couple need to manage their finances well and thoroughly while also becoming creative to generate additional income.
\end{abstract}

Keywords: Bank, Loan, Financing, Wedding Ceremony

\section{Introduction}

Marriage is generally defined as a physical and spiritual bond between a man and a woman in a household. It can not only perfect that particular needs, but also allows the intercourse between men and women as guided by the Shariah. Through marriages, human beings will not only gain peace and happiness, but also legally give birth to child in terms of law and religion (Abd. Rashid, Hussin \& Tubah, 2006).

Even though marriage provides many advantages and benefits, its implementation is now seen as gradually more difficult. The high amounts of wedding expenses have caused some young people 
to postpone their marriage until they are much older (Husin, Azahari \& Rahman, 2016). As an alternative, there are also some couple who gets their funding from various parties including banks and non-banks. Those choices have to be made to ensure the wedding ceremony to be implemented as planned.

Bloch, Rao \& Desai (2004) and Boden (2003) pointed out that among the causes of bridal couples getting funding from the bank was due to the status and willingness to perpetuate memories despite having to face high repayment commitments. That situation does not only cause them to have high debt rates at a young age, but it also makes it difficult for the couple to manage their financial. If this situation persists, various problems will arise and it will be a cause for divorce to occur even though the marriage is still new (Mat Zain, 2016).

Although there are various views on this issue, there have been no empirical studies ever been undertaken to find out about the main reason why couples get funding from banks. Apart from that, the amount of funding and repayment period also has never been a focus in any study. In addition, the type of bank that is either Islamic or conventional bank offering loans or financing is also never known. Therefore, the objective of this study is to determine the main reason why bridal couple get loans or financing from the bank, the amount of financing taken, the repayment period and the types of banks offering loans or financing.

\section{Literature Review}

The high amounts of wedding expenditure have become an important issue especially for the couple that wanted to get married. As an alternative, most of the couple who wants to get married get their funding from the bank in order to fund their wedding expenses. However, there has been little research done on this issue as those researches focused more on the marriage concepts and laws. This was including the study of Husin, Azahari \& Rahman (2016) who was debating about alTaysir on Islamic wedding expenses. The finding analysis of the study concluded that, Islam taught the ummah to simplify all affairs which related to marriage and not to burden anyone for anything beyond human capacity.

In a separate study, Husin, Azahari \& Rahman (2014) stated that the compulsory wedding expenses in Islam merely include dowry, which is an essential gift of a husband to his wife. However, Islam also encourages the walimah al-urus as a way of spreading one's marriage for public knowledge. Based on this regularity, the study concluded that the cost of wedding expenses should be low, easy and not burdensome to any party if it was implemented as outlined by Islam. Aside from that, the study of Syed Husin, Azahari \& Ab Rahman (2016) also discussed the concept of the wedding expenditure determined by the Prophet. Based on the conducted qualitative analysis, there are four ways of wedding expenditure adopted from the Prophet which includes spending on only useful things, depending on ability, simplicity and collaboration.

Meanwhile, a few quantitative study on wedding expenses were conducted, such as by Francis-Tan \& Mialon (2015). The main objective of the study was to study the relationship between 
wedding expenses and the duration of marriage. The sample of the study were consists of 3,370 married Americans. The finding showed that a high amount of spending was capable of producing a positive and long lasting marriage. While marriages involving a small amount of spending resulted in a negative and non-lasting marriage. However, the study concluded that the couple should focus more on the preparation for married lives in order to achieve a happy marital bliss.

Specifically, Abd. Hadi et al. (2016) had analysed wedding expenses according to Islamic perspectives among graduates. The quantitative study found that the average value of total wedding expenses was RM52,446 with a minimum values of RM37,907 and a maximum of RM150,500. The study concluded that the current level of wedding expenses was high and it was expected to increase from time to time. This situation was driven by many factors including high demand from couples who wants to get married. In addition, the study also found that graduates also get funding from banks to fund the wedding ceremony. Even though they are Muslim, some of them got financing from Islamic banks and a few from the conventional counterpart.

Even though there was a research that studying about the respondents who obtained their financing to fund their wedding from banks, an in depth analysis on the reasons of the funding, the amount and also the repayment were not included in the scope of this study. Thus, this study was conducted to study about that aspect in a much more in depth manner. Although there were studies focusing on the couple who obtained financing from the banks to fund their wedding expenses, they did not focus on the causes and reasons for the financing. Furthermore, the studies also did not mention about the amount and repayment period for the financing. Hence, this study is conducted to investigate on this particular aspect.

\section{Methodology}

This research was conducted as a quantitative study to identify the reasons for the community obtaining bank financing to fund the wedding ceremony. Apart from that, this study also identifies the amount of funding obtained and the repayment period of the financing. Therefore, a questionnaire form was used as a research instrument to obtain necessary information. A total of 204 respondents living in Selangor and Kuala Lumpur were involved in this study whom were selected through a snowball sampling technique. The information obtained then was analyzed descriptively.

\section{Findings}

This section is divided into two main parts. The first section will discuss the respondents' profile while the second part examines about the funding obtained by the respondents. These include the causes and reasons for the respondents to get the funding, the amount received, the repayment period, and the types of banks that offer financing.

\section{Respondent Profile}

The table below shows information regarding respondents participating in the survey. A total of 204 respondents are Muslim men, living around Selangor and Kuala Lumpur and getting some funding from banks to fund their wedding ceremony. 
INTERNATIONAL JOURNAL OF ACADEMIC RESEARCH IN BUSINESS AND SOCIAL SCIENCES

Vol. 9, No. 1, Jan, 2019, E-ISSN: 2222-6990 @ 2019 HRMARS

Table 1: Respondent Profile

\begin{tabular}{|c|c|c|c|}
\hline Respondent Profile & Details & $\begin{array}{l}\text { Frequency } \\
\mathrm{N}=204\end{array}$ & $\%$ \\
\hline \multirow[t]{3}{*}{ Highest Education } & Degree & 178 & 87.26 \\
\hline & Master & 15 & 7.35 \\
\hline & Ph.D & 11 & 5.39 \\
\hline \multirow[t]{3}{*}{ Age } & $21-25$ years old & 165 & 80.88 \\
\hline & $26-30$ years old & 30 & 14.71 \\
\hline & $31-35$ years old & 9 & 4.41 \\
\hline \multirow[t]{3}{*}{ Occupation } & Public & 102 & 50.00 \\
\hline & Private & 57 & 27.94 \\
\hline & Self-Employed & 45 & 22.06 \\
\hline \multirow[t]{9}{*}{ Net Income (Monthly) } & $\mathrm{RM} 1,001$ & 47 & 23.04 \\
\hline & $\mathrm{RM} 2,000$ & 76 & 37.25 \\
\hline & $\mathrm{RM} 2,001$ & 59 & 28.92 \\
\hline & $\mathrm{RM} 3,000$ & 15 & 7.35 \\
\hline & $\mathrm{RM} 3,001$ & 7 & 3.44 \\
\hline & $\mathrm{RM} 4,000$ & & \\
\hline & RM4,001 & & \\
\hline & RM5,000 & & \\
\hline & $\geq \mathrm{RM} 5,001$ & & \\
\hline \multirow[t]{5}{*}{ Saving (Monthly) } & None & 118 & 57.84 \\
\hline & RM100 - RM200 & 45 & 22.06 \\
\hline & RM201 - RM300 & 12 & 5.88 \\
\hline & RM301 - RM400 & 21 & 10.29 \\
\hline & $\geq \mathrm{RM} 401$ & 8 & 3.93 \\
\hline
\end{tabular}

Based on the highest level of education, nearly 90 percent of respondents have a bachelor's degree. Meanwhile, only a handful of them (5.39 per cent) hold a doctorate degree. Respondents in majority ( 80.88 percent) are between 21 and 25 years old. Only a small proportion (4.41 percent) established households when they were between 31 and 35 years old. In terms of employment, 50 percent of respondents worked in the public sector, almost 30 percent in the private sector while the rest worked on their own.

Referring to the net income, 23.04 percent had net income total between RM1,001 and RM2,000 per month. Meanwhile, nearly 40 percent of them have monthly net income of RM2,001 to $\mathrm{RM} 3,000$. Only a small number (7.35 percent) has income between RM4,001 and RM5,000 while only 3.44 percent of respondents have an income of more than RM5,000. Furthermore, nearly 60 percent 
INTERNATIONAL JOURNAL OF ACADEMIC RESEARCH IN BUSINESS AND SOCIAL SCIENCES

Vol. 9, No. 1, Jan, 2019, E-ISSN: 2222-6990 @ 2019 HRMARS

of respondents have no fixed monthly savings. Only 22.06 percent had monthly savings of RM100 to RM200, 5.88 percent had savings of RM201 to RM300 and 10.29 percent RM301 to RM400. Nonetheless, 8 respondents have monthly savings exceeding RM400.

\section{Financing Information}

The finding shows that there are six main reasons for respondents to get financing from the bank for their wedding ceremony. Nearly 60 percent of respondents stated that their main reason for obtaining a loan or financing from the bank since they have no money at all for the wedding. Meanwhile, there were 21.08 percent of respondents saying that the financing obtained from the bank was used to increase existing funds. Meanwhile, 10.30 per cent said that the main reason they get funding is to prepare for the marital life such as rent a house, purchase home furniture such as refrigerator, car deposit and others. There is also a small portion (4.90 per cent) obtaining bank financing to make money transfer. Furthermore, 4.41 percent get bank financing in preparation for a honeymoon with her partner either local or abroad.

Table 2: The Loan or Financing Information

\begin{tabular}{|c|c|c|}
\hline Focus & Details & Frequency (\%) \\
\hline The main reasons for financing & $\begin{array}{l}\text { No money at all } \\
\text { Top up existing money } \\
\text { Expenses after marriage } \\
\text { Dowry (duit hantaran) } \\
\text { Honeymoon }\end{array}$ & $\begin{array}{l}121(59.31) \\
43(21.08) \\
21(10.30) \\
10(4.90) \\
9(4.41)\end{array}$ \\
\hline Loan/Financing Amount & $\begin{array}{l}\text { RM20,001 - RM30,000 } \\
\text { RM30,001 - RM40,000 } \\
\text { RM40,001 - RM50,000 } \\
\text { RM50,001 - RM60,000 } \\
>\text { RM60,000 }\end{array}$ & $\begin{array}{l}56(27.45) \\
34(16.67) \\
98(48.04) \\
6(2.94) \\
10(4.90)\end{array}$ \\
\hline Repayment Period & $\begin{array}{l}4-5 \text { years } \\
6-7 \text { years } \\
7-8 \text { years } \\
8-9 \text { years } \\
10 \text { years }\end{array}$ & $\begin{array}{l}34(16.67) \\
88(43.14) \\
18(8.81) \\
43(21.08) \\
21(10.30)\end{array}$ \\
\hline Source of Loan/Financing & $\begin{array}{l}\text { Islamic Banks } \\
\text { Conventional Banks }\end{array}$ & $\begin{array}{l}113(55.39) \\
91(44.61)\end{array}$ \\
\hline
\end{tabular}

Furthermore, nearly 30 percent of respondents make loans or financing worth between RM20,001 to RM30,000. Meanwhile, nearly 50 per cent of respondents get a financing of between RM40,001 and RM50,000. Only a small amount of funding is worth between RM50,001 to RM60,000 (2.94 per cent) and above RM60,000 (4.90 per cent). The amount of these loans and financing differs from one another due to several factors. Among them are the money needed for the wedding and the ability to repay. 
In relation to the repayment terms of the loan or financing, 43.14 percent has a period of 6 to 7 years. There are also respondents who need to repay within 8 to 9 years of which 43 people. Only a small number of 10.30 per cent need to be paid within 10 years. Most respondents took a longer period of time to reduce the commitments they had to pay to the bank. Furthermore, more than half (55.39 per cent) of respondents obtained funding from Islamic banking and some other which is 44.61 per cent borrowed from conventional banks. Despite all Muslim respondents, some of them took the loans from conventional banks. This is because most Islamic banks reject their application for financing.

\section{Conclusion}

In conclusion, even though Islam encourages the Muslims to get married, the implementation of it in the current situation seems to be getting more difficult especially when it comes to the expenditure. Hence, most couple who wants to get married turned to bank loan or financing as an alternative. The finding showed that most respondents got loans or financing because they have no money at all to get married. Despite the amount of funding received were under $\mathrm{RM} 100,000$, however, majority of respondents are bound to a repayment period of more than 5 years. In addition, although all of the respondents are Muslim, they still get loan for marriages from conventional banks. Most of them admitted that their application for funding from Islamic banks has been rejected. Hence, they went to the conventional bank to get certain amount of loan.

Therefore, every couple who wants to get married has to make preparation from various angles. This was not just about the marital life knowledge, but also financial management before and after being married. This is important so as to avoid any problems that may arise such as divorce especially for those who have high commitment of repayment after marriage. In addition, the couple needs to be more creative to generate additional income to enable them to have savings and increase household purchasing power. This will not only benefit them in the future, but also allows them to enjoy a better life.

\section{Acknowledgment}

This paper is based on the research project entitled Corak Perbelanjaan Perkahwinan Dalam kalangan Graduan: Analisis daripada Perspektif Islam. The authors would like to extend their gratitude to the Research Management and Innovation Centre (RMIC), Sultan Idris Education University, Perak, Malaysia for the University Research Grant (Code 2015-0137-107-01) that helped fund the research.

\section{References}

Abd. Hadi, F. S., Mahjom, N., Muhammad, F., Mohd Hussin, M. Y., Zulkifli, N., Rambeli @ Ramli, N., \& Ahmad, M. A. (2016). Analisis Corak Perbelanjaan Perkahwinan dalam Kalangan Graduan. Management Research Journal, 5(1), 22-31.

Abd. Hadi, F-S., Mohd Hussin, M. Y., Muhammad, F., Abdul Razak, A., Mahjom, N., Choong, F. N., \& Ahmad, M. A. (2016). Analisis Perbelanjaan Perkahwinan Muslim Dan Bukan Muslim. Journal of Islamic, Social, Economics and Development, 2(6), 46-55. 
INTERNATIONAL JOURNAL OF ACADEMIC RESEARCH IN BUSINESS AND SOCIAL SCIENCES

Vol. 9, No. 1, Jan, 2019, E-ISSN: 2222-6990 @ 2019 HRMARS

Abd. Rashid, A. R., Hussin, S., \& Tubah, J. (2006). Institusi Keluarga: Menghadapi Cabaran Alaf Baru. Kuala Lumpur: Utusan Publications \& Distributors Sdn. Bhd.

Haq, A. N. (2012). Right of Women to Mahar (Dower) Under Islamic Law and Malaysian Family Law: Some Suggestion for Reform. Journal of Islamic Law Review, 8, 215-229.

Abdullah, F. (2009). Dari Halaman Rumah ke Dewan Merak Kayangan: Upacara Perkahwinan Melayu Bandar. SARI: Jurnal Alam dan Tamadun Melayu, 27, 97-107.

Al-Asqalani, A. I. A. I. H. (2001). Fath al-Bari bi al-Sharh Sahih al-Bukhari. Qaherah: Maktabah Misr.

Al-Husayni, T. A. D. A. B. I. M. (t.t). Kifayah al-Akhyar fi Hill Ghayah al-Ikhtisor. Beirut: Dar al-Kutub alIlmiyyah.

Al-Jaziri, A. R. (1999). Kitab al-Fiqh ala al-Mazahib al-Arba'ah. Qaherah: Dar al-Manar.

Al-Malbariy, Z. A. Z. (2008). Fath al-Mu'iin. Johor: Perniagaan Jahabersa.

Al-Mutawalli, A. A. (2010). al-Dawabit al-Qanuniyyah wa al-Shari'ah wa al-Mushkilat al-ilmiyyah li alAnwa'al-Hadithah li al-zawajwa al-Talaq. Kaherah: Dar al- Kutub al-Hadith.

Al-Sabuni, M. A. (t.t). Tafsir Ayat al-Ahkam min al-Quran. Beirut: Dar al-Kutub al-Ilmiyyah.

Azahari, R., Saripudin, K. N., \& Abd Wahab, R. (2009). Hubungan di Antara Faktor Demografi dengan Penentuan Kadar Hantaran: Kajian di Perlis, Kedah, Pulau Pinang Dan Perak. Jurnal Fiqh, 6, 107124.

Bloch, F., Rao, V., \& Desai, S. (2004). Wedding Celebrations as Conspicuous Consumption Signalling Social Status in Rural India. Journal of Human Resources, 39(3), 675-695. doi: 10.2307/3558992.

Boden, S. (2003). Consumerism, Romance, and the Wedding Experience. Barkeley: University of California Press.

Chek, R. (2010). Konsep Perkahwinan Dalam Islam Dan Kristian: Kajian Perbandingan. (Doctoral dissertation, University of Malaya).

Piaw, C. Y. (2011). Kaedah Penyelidikan (Buku 2). Malaysia: McGraw Hill.

Dain, R. (2016). Wang Hantaran Hanya Adat. Utusan Malaysia.

Djaja, T. (1980). Tuntutan Perkahwinan dan Rumahtangga Islam. Bandung: PT. Alma'arif.

Dunya, S. A. (2013). Trend Kahwin Lambat Belia Muslim. Sinar Harian.

Francis-Tan, A., \& Mialon, H. M. (2015). "A Diamond Is Forever" And Other Fairy Tales: The Relationship between Wedding Expenses and Marriage Duration. Economic Inquiry, 53(4), 1919-1930.

Hassan, A. (2007). Kualitatif Atau Kuantitatif? Memahami Andaian Asas Yang Mendasari Penyelidikan Pendidikan. Masalah Pendidikan. 30(1), 7-16.

Heng, H. L. S., \& Guan, A. T. K. (2007). Examining Malaysian Household Expenditure Patterns On FoodAway-From-Home. Asian Journal of Agriculture and Development, 3(1), 11-24.

Ibn Qudamah (1997). al-Mughni. Riyad: Dar 'Alam al-Kutub.

Idris, N. A. (2000). Teori Pertumbuhan \& Pembangunan Ekonomi. Bangi: Universiti Kebangsaan Malaysia.

Iman, A. (2010). Adat Budaya. Kuala Lumpur: Goodmark Enterprise.

Ismail, R., Yunus, J. @ N., \& Kamis, H. (2014). Analisis Data Kuantitatif. Kuala Lumpur: Kaisar Media Kreatif.

Kasimin, A. (1989). Adat Istiadat Perkahwinan Melayu, Satu Kajian Perbandingan. Kuala Lumpur: Dewan Bahasa Pustaka. 
INTERNATIONAL JOURNAL OF ACADEMIC RESEARCH IN BUSINESS AND SOCIAL SCIENCES

Vol. 9, No. 1, Jan, 2019, E-ISSN: 2222-6990 @ 2019 HRMARS

Khalid, A. (2016). Wang Hantaran Tak Cukup, Bakal Pengantin Bertumbuk. Utusan Online.

Konting, M. M. (1990). Kaedah Penyelidikan Pendidikan. Kuala Lumpur: Dewan Bahasa dan Pustaka.

Mahadzir, S. (2009). Adat Resam dan Makanan Masyarakat Melayu. Kuala Lumpur: EL Publication Sdn. Bhd..

Masud, J. (1982). Corak Perbelanjaan dan Pengurusan Di Kalangan Beberapa Keluarga Melayu dan Cina Di Wilayah Persekutuan. Pertanika, 5(1), 45-52.

Mat Zain, M. N. (2016). Usah Ikut Trend Hantaran Tinggi. Kosmo.

Muhammad 'Uqlah (2000). Nizam al-Usrah fi al-Islam. Amman: Maktabah al-Risalah al-Hadithah.

Paim, L., \& Masud, J. (1983). Corak Perbelanjaan Pekerja-Pekerja Kilang Di Paroi, Seremban dan Sungai Way, Selangor. Pertanika, 6(1), 43-47.

Pallant, J. (2005). SPSS Survival Manual: A Step by Step Guide to Data. Australia: Allen \& Unwind.

Rahman, H. A. (2010). Pegangan Adat Turun Menurun. Kuala Lumpur: Penerbit Sinar Cemerlang.

Rahman, Z. A. (2007). Mahar in Malaysia: The Law Revisited. Kuala Lumpur: Malayan Law Journal Sdn. Bhd.

Razak, M. I. M., Abidin, N. E., Yusof, M. A. M., Sakarji, S. R., \& Nor, K. M. (2014). Spending Trends among Youth in Malaysia. Journal of Economics and Development Studies, 2(1), 277-288.

Salleh, N. (2014). Tepak Sirih: Komunikasi Bukan Lisan dalam Adat Perkahwinan Melayu. Jurnal Komunikasi, 30 (Special issue), 177-190.

Salleh, N. H. M., Othman, R., Hasim, M. S., \& Jaafar, A. H. (2012). The Pattern and the Impact of Middle Eastern Tourist Spending on Malaysia's Economy. Jurnal Ekonomi Malaysia, 46(1), 53-63.

Sekhampu, T. J. \& Niyimbanira, F. (2013). Analysis of the Factors Influencing Household Expenditure in a South African Township. The International Business \& Economics Research Journal, 12(3), 279. doi: https://doi.org/10.19030/iber.v12i3.7671

Shaari, N. A. (2014). Perbelanjaan Kahwin Melampau Membawa Padah. Utusan Online.

Sobian, A. (2007). Keluarga Islam, Kemahiran Keibubapaan dan Cabaran Semasa. Kuala Lumpur:

MPH Group Publishing Sdn. Bhd.

Husin, S. N. M., Azahari, R., \& Ab Rahman, A. (2014). Konsep Al-Taysir Dalam Perbelanjaan Perkahwinan Islam. Jurnal Syariah, 22(3), 323-354.

Husin, S. N. M., Azahari, R., \& Ab Rahman, A. (2016). Analisis Konsep Perbelanjaan Perkahwinan Rasulullah SAW. Jurnal Usuluddin, 43, 109-136.

Husin, S. N. M., Azahari, R., \& Ab Rahman, A. (2016). Perbelanjaan Perkahwinan Bagi Masyarakat Muslim: Analisis Literatur. Jurnal Fiqh, 13, 23-56.

Yusoff, Z. M. (2008). Amalan Pemberian Mas Kahwin di Malaysia. Jurnal Islam dan Masyarakat Kontemporari, 1, 43-57. 